\title{
Comparative Study of External Supply Chain Risks on Operational Performance of Motor Vehicle Body Building Firms in Nakuru County, Kenya
}

\author{
Annmarie Kuria, Dr. Josphat Kwasira, Eunice Waruguru \\ Department of Entrepreneurship, Leadership and Management, Jomo Kenyatta University of Agriculture and Technology, Juja, Kenya \\ Email address: \\ marienkuria@gmail.com (A. Kuria),jkwasira7@gmail.com (Dr. J. Kwasira),yunnywa@yahoo.com (E. Waruguru)
}

\section{To cite this article:}

Annmarie Kuria, Dr. Josephat Kwasira, Eunice Waruguru. Comparative Study of External Supply Chain Risks on Operational Performance of Motor Vehicle Body Building Firms in Nakuru County, Kenya. International Journal of Economics, Finance and Management Sciences. Vol. 3, No. 5, 2015, pp. 566-576. doi: 10.11648/j.ijefm.20150305.28

\begin{abstract}
This study compared the effect of external supply chain risks on operational performance of Associated Motors and Truck World Company. The study was guided by three specific objectives; to compare the effect of up-stream market risks on operational performance between Associated Motors and Truck World Company, to compare the effect of external end-toend risks on operational performance between Associated Motors and Truck World Company and to compare the effect of demand risks on operational performance between Associated Motors and Truck World Company. The population of this study was the employees working in the Procurement Department, Production Department, Finance Department and Marketing Department of Associated Motors and Truck World Company. Primary data was collected from the two motor vehicle body building firms through structured questionnaires. The data collected was coded and analyzed through SPSS version 21. Frequency, means and standard deviation were used describe the independent and dependent variables while correlation and regression analysis with t-test were used to compare the effect of external supply chain risks on operational performance in the two firms. The results revealed that external supply chain risks do not have significant effect on operational performance Associated Motors and Truck World Company. The researcher recommended that the management of motor vehicle body building firms enhance internal systems so as to buffer the organizations from external supply chain risks.
\end{abstract}

Keywords: External Supply Chain Risks, Operational Performance, Motor Vehicle Body Building Firms

\section{Introduction}

\subsection{Background of the Study}

Firms are confronted today with new risks. Traditionally, businesses have always been faced with various risks that emanate from the environment in which they operate. These risks emanate from business operations some from within the organization others from external environment. As such, risks become part of every business environment. With the today's worldwide changes and technological development, newer sources of risks are created every day. These risks are experienced in all operational areas of businesses.

According to Dittmann (2014), supply chain operations face more risks than any other functional areas of a business. Such risks become more evident if an organization expands its operations into the global scene. This creates the need to understand sources of risks, the impact such risks have on organizational operations and the possible strategies through which risks can be managed. Cross (2010) argues that managing risk, especially on the global supply chain requires that organizations account for and bridges the differences in culture, language, values and organizational behavior.

Supply chain risks have been considered a global challenge. This is because such risks are felt in literally all parts of the world. In Asia for instance, companies have resorted to carry at least $60-70$ percent days in additional inventory so as to create a buffer from supply chain risks associated with inventory (Dittmann, 2014). In China, Green Field Operation, an international corporation developed a supply chain strategy to protect the company from supply chain risks. The company has since developed significant supply chain position in the Chinese market (Cross 2010).

In Africa, the Anglo American Platinum Investment in Zimbabwe has come up with supply chain risk management strategy that has remarkably improved business risk 
management and specifically, supply chain risk management. The potential sources of supply chain risks in Africa have been identifies to include; including organizational process, supply chain control, demand and supply factors as well as environment factors (Matshedisho, 2013). Supply chain management, faced with these risks, requires specific and adequate responses such as techniques, attitude and strategies for management of risk (Osuga et al., 2015).

In Kenya the situation is not different; organizations continue to be faced with challenges that come with supply chain risks. A study conducted by Okonjo (2014) on supply chain risk management in power supply industry revealed that the power sector firms are already implementing supply chain risk management practices. The study established that the power sector firms have suffered supply chain disruptions, especially the ones associated with stock outages. In the Kenyan public sector, there has been put into place strategies to evaluate and address the impact of supply chain risks (Amemba, 2013). In the public health sector for instance, Kenya Medical Supplies Agency (KEMSA) has put in place proactive measures to ensure procurement documentation of objectives, scope, deliverables, timing and progress in all supply chain operations, and reporting of payments.

\subsection{Statement of the Problem}

Supply chain risks have attracted a lot of attention among organizations especially in the recent past. Researchers similarly are starting to focus on the concept of supply chain risks. Studies have been done on the supply chain risks from as early as 1990s. Most of the previous studies on supply chain risk management have tended to focus on areas like risk assessment process factors that influence management's perceptions of supply risk (Zsidisin, 2003), sources of risks faced by businesses (Singh, 1998) and Proactive risk management practices (Smeltzer \& Siferd, 1998). In Africa and specifically Kenya very few studies have been conducted on the comparative study of external supply chain risks on operational performance. A knowledge gap therefore exists. For instance, Manuj \& Menter (2008) observe that no definition exists that takes into account the unique dimensions of supply chain risks. They observe that the existing literature is lose that it leaves confusion in conceptualization of external supply chain risks and makes it difficult to understand the relationship between external supply chain risks and other variables. Since external supply chain risks may have devastating effects on operational performance of an organization, the understanding of external supply chain risks and their effects on operational performance is necessary to help avert consequences of the occurrences of these risks (Camarotto, 2012). This study intended to compare external supply chain risks on operational performance of motor vehicle body building firms in Nakuru County.

\subsection{Research Objectives}

i. To establish the effect of up-stream market risks on operational performance between Associated Motors and Truck World Company

ii. To determine the effect of external end-to-end risks on operational performance between Associated Motors and Truck World Company

iii. To analyse the effect of demand risks on operational performance between Associated Motors and Truck World Company

\subsection{Research Hypotheses}

Ho1: Upstream Market Risks do not have significant effect on operational performance in Associated Motors and Truck World Company.

Ho2: External end-to-end risks do not have significant effect on operational performance in Associated Motors and Truck World Company

Ho3: Demand risks do not have significant effect on operational performance in Associated Motors and Truck World Company.

\section{Literature Review}

\subsection{Theoretical Review}

The study was based on contingency fit and constraints theories discussed in the following section

\subsubsection{The Contingency Fit Theory}

The contingency fit theory provides a foundation for minimizing the magnitude of supply chain disruptions. The theory is built on the premise that outcome/results is an outcome of application of numerous factors (Standing \& Kauffman, 2007). The outcomes of management efforts in managing supply chain risks require concerted effort not only from the organization but also from other supply chain members.

The contingency theory is based on the following guidelines; the first guideline is collaborative information sharing between the supply chain partners to enhance role understanding and participative implementation. The second guideline is directing material flows to protect the affected areas. The third guideline is flow of funding to ease the flow of materials into the organization. The last guideline is building the disrupted supply chain by utilizing operational strategies of supply chain management (Kauffman at al., 2007).

In this study, this theory explains the role of management in containing supply chain risks. Management can be guided by this theory especially in allocation of duties and responsibilities as well as resources. Similarly, the principles outlined explain why many organizations that take 'casual approach' to supply chain risk management fail.

\subsubsection{The Theory of Constraints}

The theory of constraints is based on five steps; the first step is to identify the system's constraints. The management must identify the potential constraints that may limit its risk management initiatives. The second step is to exploit the system's constraints. The organization's constraints should 
not at all time be considered as a problem. The organization must maximize on the opportunities presented by these constraints. The third step is to make decisions and subordinate everything else above the decisions. The next step is to evaluate the system's constraints so as prioritize on how to handle the constraints (Rand et al., 2000).

Many organizations blame poor supply chain risk management on organizational constraints. Therefore, according to Adriano et al. (2013), organizations should adopt a constraint based risk management system. The organization must be robust in the supply chain risk management system that considers all potential constraints; financial, human resource and good will constraints. In this study, this theory explains the role of management, how management should go about containing internal limitations to achieve optimal results as far as supply chain risks are concerned.

\subsection{Empirical Review}

The independent and dependent variables were broken down into indicators. The indicators on external supply chain risks and operational performance are discussed in this section.

\subsubsection{External Supply Chain Risks}

External supply chain risks involve the potential occurrence of events associated with inbound and outbound supply operations that can have significant detrimental effects on purchasing firms (Zsidisin et al., 2000). External supply chain risks include; the legal risks, financial risks, ethical risks, security and supply risks, price volatility risks, organizational reputation risks. "External supply chain risks deal with environmental causes that can barely be influenced and lead directly or indirectly to disturbances within the supply chain" (Thun \& Hoenig, 2011).

The current business environment is characterized by a lot of uncertainty and complexity. Organizations, especially manufacturing ones operating in such business environments are faced with a lot of challenges emanating from the external supply chain (Jüttner et al. 2003). Commons challenges from external supply chain include; supplier losses or quality problems make supply chain risk management important (Thun \& Hoenig, 2011). When an organization goes global in its operations, the organization becomes even more vulnerable. This is because external supply chains such as transportation risks, cultural diversification risks and exchange risks become more intense (Rice \& Caniato, 2003).

Most authors have conceptualized external supply chain risks into demand risks, supply risks, environmental risks and security risks. Wilding (2003) argues that external supply chain risks can be conceptualized in terms of demand related risks, supply related risks and supply chain environment related risks. Manuj \& Mentzer (2008) on the other hand argues that external supply chain risks can be conceptualized into; demand, supply and security risks. In this study, external supply chain risks will be studied in terms of supply risks, environmental risks and demand risks.

\subsubsection{Upstream Market Risks}

According to LCP Consulting (2003), 'supply chain relates to potential or actual disturbances to the flow of product or information emanating within the network, upstream of the focal firm'. Upstream market risks occur when a supply chain cannot meet the supply needs of the organization. Such risks occur when the supply chain in unable to deliver the right quantity of required materials or delivers materials late. Upstream market risk is also associated with supplier's inability or inadequacy to satisfy the organization's supply needs. Such risks include; poor supplier appraisal, selection and management, cash flows problems and financial difficulties (Jüttner et al, 2003).

Upstream supply chain risks may have very adverse effects on an organization if not well managed. Such effects include; emergence of back orders, late deliveries that leads to discontinuous operations, increased costs on managing defective and rejected materials, delays in internal processes and organizational projects, failure costs and extra inventory costs. Upstream supply chain risks especially those related to environmental management, non-compliance with trade and government regulations and unethical practices may also adversely affect the reputation of the organization in addition to its ability to meet market needs (Lee Buddress, 2014).

While upstream risks are largely blamed on external based failures and failures in the transport network (Director Notes, 2013), Tomas et al. (2013), an organization may also contribute to occurrence of supply risks especially due to poor supplier management by the organizations. Management issues that have been pointed out include; poor information management between the organization and its suppliers making it difficult to plan supplier activities like delivery of materials and poor production planning and demand forecasts that hinder suppliers ability to meet organizational needs. Apart from the external factors and internal organizational deficiencies, upstream market risks may also emanate from supplier deficiencies such as; production problems, inadequate finances and social responsibility failures (Braithwaite, 2003).

\subsubsection{External End-to-End Risks}

The current business is very volatile, turbulent and characterized with a lot of uncertainties (DN, 2014). LCP Consulting (2003) associates external end-to-end risks to potential risks in supply chain environment. Such risks include; natural disasters, accidents, sabotage, terrorism, crime, war, political uncertainty, labor unavailability, market challenges, lawsuits and technological trends. Natural Disasters include; epidemics, earthquakes, tsunamis, volcanoes and weather disasters. Accidents include; unexpected fires, explosions, structural failures and hazardous spills. On the other hand, sabotage in the supply chain may be caused by terrorism, crime, and war. Government compliance relates to taxes, customs, and other regulations while technological risks relates to emerging technologies, obsolescence and other technological 
uncertainty (Lee Buddress, 2014).

These factors are beyond the control of the organization and may adversely affect the organization if not well managed. Supply chain end-to-end risks include risks related to disruptions to supply or increased supply costs arising from market and environmental factors (Manuj \& Mentzer, 2008). Director Notes (2013) points out that government regulations and actions form an integral part of the supply chain environment. Changing government regulations on purchasing, pricing and other supply chain activities have a direct influence on the supply chain operations of an organization. These regulations may present themselves as a risk if an organization fails adopts the correct response strategies (DN, 2014).

According to Choi \& Zang (2011), supply chain security cannot be overlooked when discussing end-to-end supply chain risks. Supply chain security risks include all security issues in the supply chain system. Such risks include; information system security, crime and sabotage issues. With the advancement in technology, the organizations get exposed to a lot if cyber-crime and security threats. It is recommended that organizations adopt statutory regulations to secure their supply chain from such threats (Manuj \& Mentzer, 2008). DN (2014) points out that an organization can develop systems for the following aspects of supply chain security; physical security, access controls, personnel security, procedural security, business partner security and conveyance security. Avoidance strategy may be adopted where possible (Choi \& Zang, 2011).

External supply chain environment also presents security risks. Security risks are considered critical risks that every serious organization must understand and manage. This is because such risks are more likely to occur, especially in the global supply chain environment (Lee Buddress, 2014). In addition, these risks are accompanied by grave consequences when they occur (Tomas et al., 2013). It is important to understand the supply chain environment and identify potential security risks and develop workable supply chain risk management (Manuj \& Mentzer, 2008 and Choi \& Zang, 2011).

\subsubsection{Demand Risks}

Demand risk may be categories as both internal and external demand risks. The factors of demand risk that relate to external supply chain risks include; demand issues such as demand fluctuations, unexpected high demand and unexpected low demand (CIPS, 2014 and Manuj \& Mentzer, 2008). According LCP Consulting (2003), demand supply chain risks relates to potential or actual disturbances to flow of product, information, and money, emanating from within the network from the organization to the market. They relate to the activities, processes, controls, networks and infrastructure of the organization's downstream supply chain.

As discussed in LCP Consulting (2003), an organization can protect itself from demand risks through the following strategies. Firstly, the organization may focus on protecting itself from uncertainties in market demands by positioning itself through adequate inventory management system that creates a buffer from such externalities. Secondly, the organization may enhance the internal capacity to meet external demand. The organization must be flexible enough to adopt to market demand fluctuations without serious problems. Lastly, organization may adopt better sourcing strategies such partnership and dual sourcing to ensure there is continuous flow of inputs.

Supply Chain Risk Leadership Council (2011) points out that demand risks occur due to disruption in disruptions in the outbound supply chain. Such disruptions may be caused by factors such as; infrastructure unavailability, labour unavailability, warehouse inadequacy, inadequate capacity, cargo damage or theft and information system failures and inadequacies. These disruptions negatively affect the efforts of the organization to meet demand

\subsubsection{Operational Performance}

Organizational performance can be defined as the extent to which an organization achieves set goals and objectives (Muma et al, 2014). Organizational performance can be looked at in terms of various aspects; financial performance, social performance, environmental performance and operational performance (Choi \& Zang, 2011). From supply chain management point of view, operational performance may take dimensions of time, cost, quality, agility and leanness (Norrman, 2004).

According to Hassan (Hassan, 2013), operational performance indicators include; increased savings and cost saving, enhanced quality in both inputs and the end product, improved competitiveness and increased market share, ability to identify and take advantage of opportunities, enhanced employees motivation and productivity and increased sales. An operationally performing organization is an organization that is able to achieve decreased cost for materials purchasing, decreased cost for energy consumption, decreased costs for waste treatment, decreased cost for waste discharge and decreased costs associated with environmental accidents in their operations (Ninlawan et al., 2010).

Green et al. (2012) appreciates that improved operations leads to increase in the amount of goods delivered on time, decrease in inventory levels, decrease in scrap rate, increase in product quality, increase in product line, improved capacity utilization. Thun \& Hoenig (2011) points out that supply chain risks have inherent consequences. They cause disruptions that may negatively impact on organizational operations. However, when these risks are managed through and effective risk management system, such organizations become more productive and profitable. "Organizations require agility in their supply chains to provide superior value as well as to manage disruption risks and ensure uninterrupted service to customers" (Suresh \& Braunscheidei, 2008).

\subsubsection{Supply Chain Risk Management}

To handle external supply chain risks, an elaborate risk management system is necessary. Risk management, is a formal process that involves identifying potential losses, understanding the likelihood of potential losses, and 
assigning significance to these losses (Giunipero \& Eltantawy, 2004). Supply chain management seeks to reduce risks associated with procurement process and enhance competitive performance of the organization by closely integrating internal functions within the firm and effectively linking them with the external operations of suppliers, channel members and final customers.

Supply chain management is an elaborate and complex process. The process starts with identification of critical supply areas and prioritizing these areas in terms of the how critical they are to the organization. From these areas, the potential risks are identified. At this stage, the characteristics such as risk interdependency and intensity are considered through an elaborate risk analysis. Risk analysis is important in coming up with proactive risk management strategies. It also helps the organization to predict the potential intensity and impact of the risk which is critical in risk management implementation (Musa, 2012). Another important activity of supply chain risk management is risk reporting. Risk reporting provides essential information on risk characteristics and other information essential for supply chain management. Management of supply chain risks requires a well-coordinated risk management framework. A good risk management system should be comprehensive, robust and should integrate all supply chain activities. The system should also allow for flexibility (Accenture, 2012).

Supply chain stakeholders especially in positions to make decisions must have the ability to understand risk and prepare strategies to mitigate the consequences of risks. Some of the factors that create risk in procurement may include product availability; distance from source, demand fluctuations, changes in technology, financial instability (MacKinnon, 2002). Risk management in procurement is continuous process that involves long term dedication of supply chain members. Ongoing risk assessment process includes: gathering, communicating and evaluation information that aid in developing smart risk management strategies. Risks may be due to disrupted supply, transportation risks. To manage risks effectively, methods that may be used include: working closely with channel members, mergers and alliances formation, use of e-procurement to integrate supply chains, joint buyer supplier efforts and other measures (Stemper, 2002; Antonette, 2002; Cavinato \& Kauffma, 2000).

Supply chain risk management can be used by an organization to achieve operational performance objectives. This is because supply chain management leads to enhanced efficiency, minimum wastages and reduced operational costs. It also leads to enhanced credibility and improved reputation of the organization. A well implemented supply chain risk management strategy adds value to the organization and creates competitive advantage. This is because of the following reasons; supply chain risk management enables better understanding of supply chain risks from the management point of view thereby enhancing organization's response to such risks. It facilitates control and influence over suppliers, thereby reduces the chances of risks occurring. Enhanced supply chain risk management leads to improved efficiency and reliability (DNV Business Assurance, 2014).

A supply chain risk has been conceptualized differently by different scholars. A guide developed by Department of Transport, Granfield University (2003) discussed four levels of supply chain risks. The first level approaches supply chain risks from an idealized integrated end to end supply chain management system. Level two supply chain risks are dependent on assets and infrastructure. Level three is linked with organizations and inter-organizational networks while level four is linked to the environment. These levels of risks can cause disruption in supply chain interfering with the organizations ability to ensure efficiency and effectiveness.

According to Manuj \& Mentzer (2008), supply chain risks can be classified into four categories; macroeconomic risks associated with significant economic shifts, policy risks associated with unexpected actions of national governments, competitive risks associated with uncertainty about competitor activities in foreign markets and resource risks associated with unanticipated differences in resource requirements.

Supply chain risks can be conceptualized into internal and external supply risks; internal supply chain risks associated with inventory ownership, assets and tools ownership, product quality and safety. Other aspects of internal supply chain risk include demand variability, demand forecast errors, competitor moves and other risks affecting customers. External associated with supplier opportunism, inbound product quality and transit time variability. Other external supply chain risks are associated with macroeconomic changes, state of security and inefficiencies in the global market (Manuj \& Mentzer, 2008).

\subsubsection{External Supply Chain Risks and Operational Performance}

Thun \& Hoenig (2011) conducted a study on supply chain risk and organizational performance. They found out that supplier related risks such as; supplier quality problem and supplier failure are considered as the most critical risks. This is because such risks have very high level of probability and high impact on the internal supply chain performance than any other factor. However, this does not mean that external supply chain risks are any better. Majority of external supply chain risks are grave in the level of their consequences when they occur. The study revealed that most manufacturing organizations adopt reactive and preventive supply chain risk management. The firms adopting reactive supply risk management have higher average value in disruption resistance. Organizations that adopt preventive supply chain risk management on the other hand enjoy better values concerning flexibility of operations.

Suresh \& Braunscheidei (2008) conducted a research on the organizational antecedents of a firm's supply chain agility for risk mitigation and response. In this study, it was evident that organizations are vulnerable to supply chain risks. The study set out to investigate how supply chain agility could be improved and whether it can enhance supply chai risk 
management. The study revealed that supply chain agility can be enhanced through; internal integration of key functional areas within the organization and external integration with suppliers and customers. Other than internal and external integration, external flexibility was also identified as a driver for augmenting supply chain agility. This study also noted that supply chain agility has direct link with operational performance.

Manuj \& Mentzer (2008) researched on global supply chain risk management strategies. The study revealed that supply chain risks still remain a challenge to many organizations, especially those operating internationally. In the study they developed a model that looks at supply chain risks in terms of supply risks, demand risks and operational risks. They found out that the organizations adopt different supply chain risk managements. The first strategy is speculation, where risks are managed selectively based on the principle that changes in form movement of goods to forward inventories, should be made at the earliest possible in order to reduce the costs incurred in supply chain. The second strategy is hedging where supply chain risks are managed by having a dispersed portfolio of suppliers and activities. The third strategy is control, share or transfer. Risks can be transferred both vertically and horizontally within the supply chain. Other strategies include enhancing supply chain security and avoidance of supply chain operations with high risk propensity.

\subsection{Conceptual Framework}

Smyth (2004) observes that a conceptual framework helps a researcher to properly identify the problem he is looking at, frame questions and find suitable literature. The independent variables for this study will be training in project management while the dependent variable will be project performance. The relationship is presented in figure 1

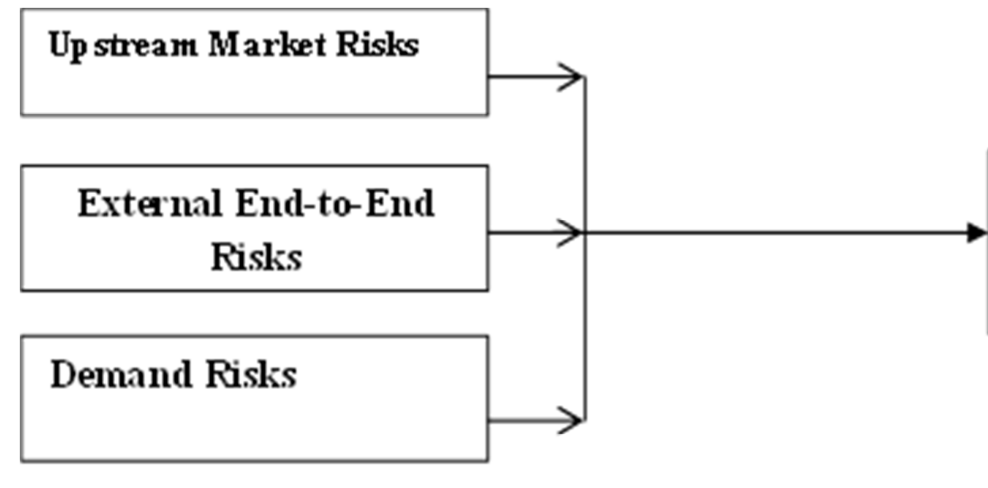

Independent variable

\section{Operational \\ Performance}

\section{Dependent variable}

Figure 1. Conceptual Framework.

\section{Methodology}

\subsection{Research Design}

Research design describes the pattern the research intends to follow in achieving the objectives of the study (Oso \& Onen, 2011). It is the arrangement of conditions for collection and analysis of data so as to achieve the objective of the researcher in the most accurate, efficient and economical way (Kothari, 2011). The researcher adopted comparative research design. Comparative research design compares one or more characteristics of a group to discover the extent to which the characteristics vary together (Simon, 2011) or how the variables relate (Oso \& Onen, 2011). A cross sectional survey was adopted for this study. A cross sectional survey is where data is collected at a single point in time (Muma, 2014). The study collected qualitative data.

\subsection{Target Population}

Mugenda \& Mugenda (2013) describe population as a total collection of elements about which inference is made for the purpose of research. This study aimed to compare the external supply chain risks on operational performance of motor vehicle body building firms in Nakuru County, the population in this study was therefore employees in the motor vehicle body building firms in Nakuru County. Since Car and General Motors will be involved in the pilot study, Target population for this study was the employees in Associated Motors and Truck World. Target population was the portion of entire population in which the researcher is interested, has access to or is more likely to get the required data (Oso \& Onen, 2011).

\subsection{Sample Size and Sampling Procedure}

The sample frame for this study was purposively selected. Employees in procurement, production, finance and marketing departments will be the sample frame. Employees in the four departments were selected because they have direct link with the supply chain activities and have understanding on indicators of operational performance. There are a total of 63 employees in the four departments in the two companies Because of the small number; all the 63 
employees were involved in the study. The distribution of the respondents per department is shown in table 1.

Table 1. Distribution of Sample Frame Elements.

\begin{tabular}{llll}
\hline Associated Motors & \multicolumn{3}{c}{ Truck World Motors } \\
\hline Department & No & Department & No \\
\hline Procurement Department & 12 & Procurement Department & 6 \\
Production Department & 3 & Production Department & 3 \\
Finance Department & 10 & Finance Department & 6 \\
Marketing Department & 12 & Marketing Department & 11 \\
Total & 37 & & 26 \\
\hline
\end{tabular}

\subsection{Data Collection Instrument}

Data collection instruments are the tools used in collection of data (Oso \& Onen, 2011). The researcher developed structured questionnaires to collect primary data. Structured questionnaires are easy to analyze since they are on their immediate usable form, (Kothari, 2004). The research questionnaire had five sections; background information section, three sections on the indicators of external supply chain risks and a section on operational performance. Each section had research items on the variables of interest. Since data collected is qualitative, a five points' likert scale was developed and used. Questionnaires were preferred because the information needed for this research could be easily described in writing. In addition, the respondents who did not enough time for interviews were able to fill the questionnaires at their own free time thereby improving respondents' response. Each item in the questionnaire was developed to address a specific objective.

\subsection{Data Collection Procedures}

The researcher obtain a letter of introduction from JKUAT administration, thereafter authorization to collect data was sought from the management of Associated Motors and Truck world companies to conduct the research. The questionnaires were administered through drop and pick technique. The respondents were given one week to fill the questionnaires after which they were collected by the researcher for analysis.

\subsection{Pilot Test}

According to Kothari (2011), before using the research questionnaires, the questionnaires should be tested through a pilot study. A pilot study was conducted in Car and General Company. Mugenda \& Mugenda (2003) recommend that the sample to be used in the pilot test should be between $1 \%$ and $10 \%$. A total 12 questionnaires were issued to employees in the procurement, production, finance and marketing departments. A pilot test brings out the weakness of (if any) the questionnaire (Kothari, 2004) and enables the researcher to assess the questions validity and likely reliability of the data that will be collected. A content validity test was conducted to ensure all indicators measured are adequately represented. According to Kothari (2004), content validity is a function of whether the dimensions or elements of a concept have been captured. Reliability is the extent to which results of a study are consistent over time and there is an accurate representation of the total population under study and aims to establish the ability of the research instruments to produce similar results over time (Golafshani, 2003). The Cronbach's Alpha was computed for every variable in the study through SPSS. The overall alpha was obtained as shown in Table 2.

Table 2. Pilot Test Results.

\begin{tabular}{lll}
\hline Items & Cronbach's Alpha & No. of Items \\
\hline Upstream Market Needs & 0.804 & 14 \\
External end to end risks & 0.759 & 12 \\
Demand risks & 0.692 & 10 \\
Operational Performance & 0.701 & 16 \\
Alpha $(\alpha)$ & 0.739 & 30 \\
\hline
\end{tabular}

Table 2 shows the mean of Cronbach's alpha as calculated through SPSS. Mean Cronbach's alpha value of 0.739 was obtained. This result was greater than the threshold 0.7 and the items were therefore considered as reliable.

\subsection{Data Analysis and Presentation}

Once all questionnaires had been collected, the questionnaires were checked for completeness. They were then be coded and edited through SPSS version 21. Both descriptive (frequencies, means and standard deviation), comparative analysis and inferential (regression test) analysis were conducted. Descriptive analysis will be used to describe the independent and dependent variables; comparative analysis was used to compare the variables in the two companies while inferential analysis will be used to determine the effect of external supply chain risks on operational performance. The results of the study were presented using tables. The general regression model below guided the study.

$$
Y=\beta 0+\beta_{1} X_{1}+\beta_{2} X_{2}+\beta_{3} X_{3}+\varepsilon
$$

Where; Y - Operational Performance

$\beta 0$ - Constant

$\beta_{1}-\beta_{3}$ - Regression coefficients

$\mathrm{X} 1$ - Up- stream market risks

$\mathrm{X} 2$-External End-to End risks

$\mathrm{X} 2$ - Demand risks

$\varepsilon$ - Error term

\section{Research Findings}

\subsection{Descriptive Analysis}

The researcher analyzed the research indicators descriptively. The findings of the were as presented in table 3. 
Table 3. Descriptive Analysis on the Variables.

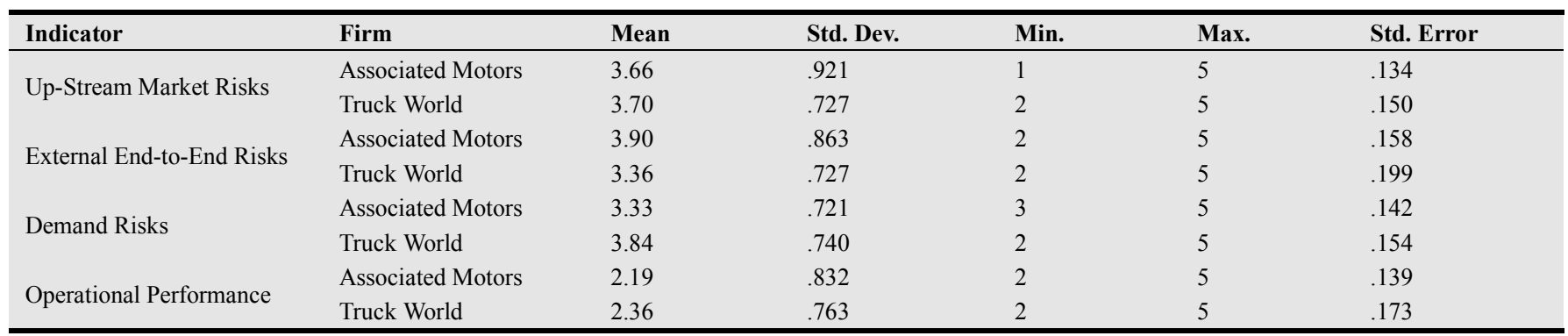

From table 3 , the means of 3.66 and $3.70(>3.00)$ reveal that the two companies experience relatively high level of upstream market risks. There was no much difference in the upstream markets risks experienced by Associated Motors and Truck World Company shown by the small difference (0.01) between the means. However, standard deviations; $0.921(>0.727)$ reveal that the response on upstream risks in Associated Motors was more diverse. This is also shown by the difference in the minimum values (1 and 2) recorded in the two companies. Since 3.70 ( $>3.66$ ), we can conclude that Truck World is exposed to relatively higher level of upstream market risks. The means of 3.90 and $3.36(>3.00)$ reveal that the two companies experience relatively high level of external end to end risks. The standard deviations of $0.863(>0.727)$ show that external end to end risks experienced by Associated Motors are more diverse as Truck World Company reveal that the two companies experience relatively similar external end to end risks. However, since 3.90 (> 3.36), it can be assumed that Associated Motors experiences relatively higher level of external end to end risks. Similarly, the means of 3.33 and 3.84(>3.00) show that the two companies experience relatively high level of demand risks. The standard deviations of $0.721(<0.740)$ indicates that Truck World Company experiences a more diverse demand risks as compared to Associated Motors. Lastly, the means 2.19 and $2.36(<3.00)$ reveal that the two companies experience relatively lower operational performance. The higher mean for Associated Motors reveal that the company experiences relatively higher operational performance as compared with Truck World.

\subsection{Correlational Analysis}

To compare the relationship between external supply chain risks and operational performance between Associated Motors and Truck World Company, correlation analysis was conducted. The results of the correlation tests were as shown in table 4.

Table 4. Results of Correlational Analysis.

\begin{tabular}{llll}
\hline & & & Operational Performance \\
\hline \multirow{3}{*}{ Truck World } & Upstream Market Risks & Pearson Correlation (r) & -.087 \\
& & Sig. (1-tailed) & .240 \\
& External-end-to-end Risk & Pearson Correlation (r) & -.050 \\
& & Sig. (1-tailed) & .342 \\
& Demand Risk & Pearson Correlation (r) & -.340 \\
Associated Motors & Sig. (1-tailed) & .002 \\
& Upstream Market Risks & Pearson Correlation (r) & -.118 \\
& & Sig. (1-tailed) & .208 \\
& External-end-to-end Risk & Pearson Correlation (r) & -.024 \\
& & Sig. (1-tailed) & .435 \\
& Demand Risk & Pearson Correlation (r) & -.043 \\
& & Sig. (1-tailed) & .383 \\
\hline
\end{tabular}

From table $4, \mathrm{r}=-0.087$ and $\mathrm{p}=0.240>0.05$ reveal statistically insignificant negative relationship between upstream market risks and operational performance in Truck World. $r=-0.050$ and $p=0.342>0.05$ reveal statistically insignificant negative relationship between external end-toend risks and operational performance in Truck World Company. Lastly, $r=-0.340$ and $\mathrm{p}=0.002<0.05$ reveal statistically significant negative relationship between demand risk and operational performance in Truck world. Values $\mathrm{r}=$ 0.1118 and $p=0.208$ reveal statistically insignificant negative relationship between upstream market risks and operational performance in Associated Motors. $r=-0.024$ and $p=0.435$ reveal statistically insignificant relationship between External-end-to-end Risk and Operational Performance of Associated Motors. Lastly, $\mathrm{r}=-0.043$ and $\mathrm{p}=0.383$ reveal statistically insignificant relationship between Demand Risk and Operational Performance of Associated Motors.

\subsection{Regression Analysis}

Regression analysis was conducted to compare the effect 
of external supply chain risks on operational performance of two companies. The results were as presented in table 5 .

Table 5. Comparison of Regression.

\begin{tabular}{lcclc}
\hline Model & $\mathbf{R}$ & $\mathbf{R}^{2}$ & Adjusted R $^{2}$ & Std. Error \\
\hline Associated Motors & $.140^{\mathrm{a}}$ & .020 & -.044 & .810 \\
Truck World Company & $.123^{\mathrm{b}}$ & .015 & -.049 & .931 \\
a. Predictors & : (Constant), Upstream Market Risks \\
Risk & , External-end-to-end \\
b. Predictors & : (Constant), Upstream Market Risks \\
, External-end-to-end \\
Risk $_{2}$, Demand Risk
\end{tabular}

Table 5 presents the regression models for the two companies. R-square represents the extent to which Upstream Market Risks, External-end-to-end Risk, Demand Risk affects operational performance. $\mathrm{R} 2=0.020$ and $\mathrm{R} 2=0.015$ imply that Upstream Market Risks, External-end-to-end Risk and Demand Risk collectively explain $2.0 \%$ and $1.5 \%$ of the changes in operational performance in Associated Motors and Truck World Company respectively. From these findings, it is clear that the effect of upstream market risks, externalend-to-end risk and demand risk is stronger in Associated Motors than Truck World Company. This implies that Associated Motors is relatively more vulnerable to external supply chain risks than Truck World Company.

The small insignificant effect could be explained by the supply chain risk management strategies adopted in by Motor Vehicle building firms such as; objective facility selection, transportation route optimization, product flow path optimization and consolidated center selection and analysis (Truck World, 2015)Both Associated Motors and Truck World companies prioritize customer service as their core objective and adopt all proactive measures in ensuring they do not compromise on customer service in all their operations.

Table 6. ANOVA Table.

\begin{tabular}{lllllll}
\hline Model & & $\begin{array}{l}\text { Sum of } \\
\text { Squares }\end{array}$ & Df & $\begin{array}{l}\text { Mean } \\
\text { Square }\end{array}$ & F & $\begin{array}{l}\text { Sig. } \\
\text { (p) }\end{array}$ \\
\hline \multirow{2}{*}{ Associated } & Regression & .603 & 3 & .201 & .306 & $.821^{\text {a }}$ \\
Motors & Residual & 30.217 & 46 & .657 & & \\
& Total & 30.820 & 49 & & & \\
Truck & Regression & .610 & 3 & .203 & .234 & $.872^{\text {a }}$ \\
World & Residual & 39.870 & 46 & .867 & & \\
& Total & 40.480 & 49 & & & \\
\hline
\end{tabular}

a. Predictors ${ }_{1}$ : (Constant), Upstream Market Risks ${ }_{1}$, External-end-to-end Risk $_{1}$, Demand Risk 1

a. Dependent Variable: Operational Performance ${ }_{1}$

b. Predictors $s_{2}$ : (Constant), Upstream Market Risks 2 , External-end-to-end Risk $_{2}$, Demand Risk 2

b. Dependent Variable: Operational Performance ${ }_{2}$

From table 6 , the significance values of $0.821>0.05$ and $0.872>0.05$ reveal that the effect of external supply chain risks on operational performance in the two companies is statistically insignificant. This implies that exposure of these two companies to external supply chain risks does not lead to statistically significant negative effect on operational performance. As evidenced by Associated Motors (2015), the company has progressive risk management strategies that protect its internal operations from the adverse effects of market dynamics and external supply chain risks. Truck world equally has internal strategies that ensure optimal operational efficiency and protection from external risks

Table 7. Table of Co-efficient.

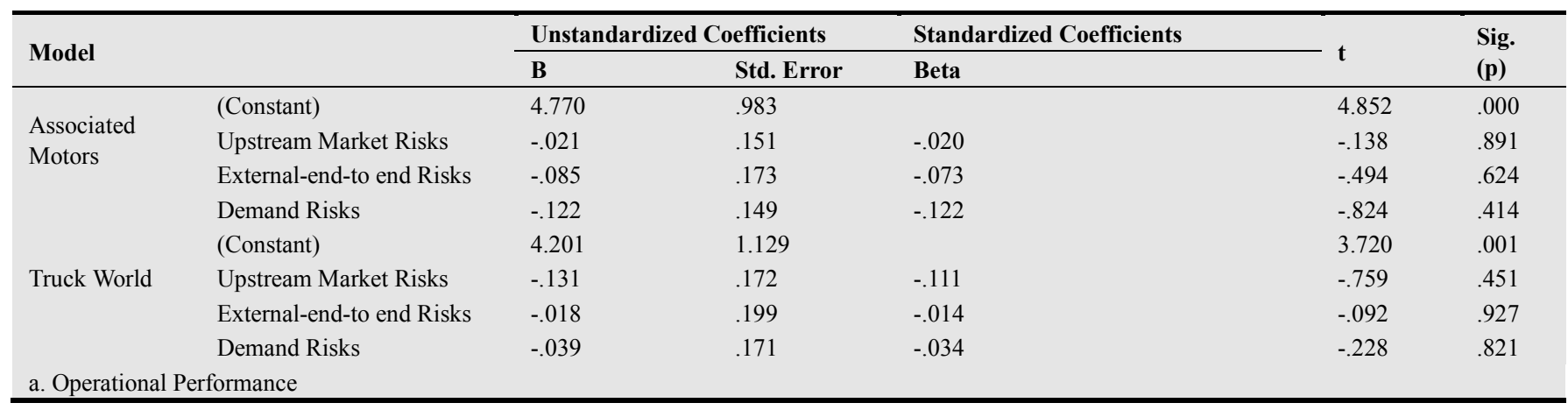

The hypotheses for the study were tested as follows;

Ho1: Up-stream market risks do not have significant effect on operational performance in Associated Motors and Truck World Company

The value of $\mathrm{t}=-0.138$ and $\mathrm{p}=0.891 \quad(>0.05)$ for Associated Motors and $\mathrm{t}=-0.759$ and $\mathrm{p}=0.451(>0.05)$ for Truck World reveal statistically insignificant effect of upstream market risks of operational performance in the two companies. The first hypothesis was therefore accepted and conclusion made that there is no significant difference between the effect of up-stream market risks on operational performance in Associated Motors and Truck World Company.
Ho2: External end-to-end risks do not have significant effect on operational performance in Associated Motors and Truck World Company

The correlation analysis revealed $\mathrm{t}=-4.94$ and $\mathrm{p}=0.624$ $(>0.05)$ for Associated Motors and t -.092 and $\mathrm{p}=0.927(>0.05)$ for Truck World implies that there is statistically insignificant effect of external end-to-end risks on operational performance in Associated Motors and Truck World Company. The second hypothesis was therefore accepted and conclusion made that there is no significant difference between the effect of external end-to-end risks on operational performance in Associated Motors and Truck World Company. 
Ho3: Demand risks do not have significant effect on operational performance in Associated Motors and Truck World Company.

The $\mathrm{t}=-0.824$ and $\mathrm{p}-0.414(>0.05) ; \mathrm{t}=-0.228$ and $\mathrm{p}=0.821$ for Associated World and Truck World Company respectively revealed statistically insignificant negative effect between demand risk and operational performance in in Associated Motors and Truck world Company. The third hypothesis was similarly accepted and conclusion made that there is no significant difference between the effect of demand risks on operational performance in Associated Motors and Truck World Company

From these findings, it was evident that both Associated Motors and Truck World Company experience statistically significant negative effect between external supply chain risks and operational performance. This implies that the more the two companies are exposed to external supply chain risks, the more they are likely to face inefficiencies and disruptions in their internal operations leading to poor operational performance.

Table 8 indicates the coefficients of the indicators for regression model for the two indicators. From the table, the following regression analysis can be derived for Associated Motors and Truck World Company.

$\mathrm{Y}=4.770-.021 \mathrm{X}_{1}-0.085 \mathrm{X}_{2}-0.122 \mathrm{X}_{3} \ldots$ model for Truck World Company

$\mathrm{Y}=4.201-0.131 \mathrm{X}_{1}-0.018 \mathrm{X}_{2}-0.039 \mathrm{X}_{3} \ldots$. model for Associated Motors

Where; Y - Operational Performance

$\mathrm{X} 1$ - Up-stream market risks

$\mathrm{X} 2$ - External End-to- End risks

X2- Demand Risks

\section{Conclusions and Recommendations}

The first conclusion was made that Associated Motors and Truck World Company exposed to relatively higher level of upstream market risks. The two companies operate in the same market environment and as are exposed to similar supplier and product inflow related risks. Associated Motors and Truck World Company both experience statistically significant negative effect of upstream market risks on operational performance.

Secondly, it was concluded that Associated Motors and Truck World companies experience relatively high level of relatively similar external end to end market risks. The two companies are in the same line of business and target the same market. They are therefore exposed to similar economic, political, regulation and technological environments exposing them to similar external supply chain environmental factors. The two companies experience statistically insignificant negative effect of external end to end risks on operational performance. The more these companies are exposed to external end to end risks, the more they are likely to face inefficiencies and disruptions in their internal operations leading to poor operational performance.
The third conclusion was made that Associated Motors and Truck World companies experience relatively high level of similar demand risks. Demand risks are inevitable for companies that target diverse markets. The demand patterns, forecasts and lead times are critical risk factors that may adversely affect the operations of an organization. It was concluded that there is insignificant negative effect of demand risk on operational performance in in Associated Motors and Truck world Company. The effect is however stronger in Associated Motors than Truck World Company implying that Associated Motors is more vulnerable to demand risks than Truck World Company.

The management of motor vehicle body building companies should identify the specific upstream market factors that may present risks to their operations. Since the organizations already have in place supply chain risk management systems and strategies, the existing strategies on upstream market risks need to be integrated with the long term organizational strategies to ensure consistency and sustainability in risk management.

The companies should adopt a strategic approach with clear and well communicated management policies for management of end to end risk. The policies should be aligned with the strategic goals and directions of the organization. Everyone in the organization must be trained on supply chain risk management and the roles each individual can play in supply chain risk management. In addition, the companies may consider developing partnership and supplier relationship with few reliable suppliers who can then reliably and cost effectively meet their internal demand needs. This can be achieving through development of information system that allows free flow of information between the company and its suppliers.

With the existing measures to protect the internal operations of the firms from adverse effects of demand risks, the firms need to improve on emergency response and recovery systems reinstate the firms in the event the firms are subjected to adverse demand risks. These strategies must be backed with adequate resources and employee training to ensure they succeed.

From the findings and recommendations of this study, the following areas are suggested for further studies; further studies should be conducted to relate internal supply chain risks with operational performance. Similar studies should also be conducted to relate external supply chain risks with other aspects of organizational performance, especially the firm's ability to satisfy customer.

\section{References}

[1] Acenture, L. A. (2012). The New Game of Supply Chain Risk Management Pursuing high performance in uncertain times. Acenture.

[2] Alankar, A. B. (2013). The Cost of Constraints: Risk Management, Agency Theory and Asset Prices. Stanford University Graduate School of Business Research Paper No. $2135 ; 13-5$. 
[3] Associated Motors. (2015). Retrieved October 10, 2015, from About Us: http://www.associated-motors.com/.

[4] Assurance, D. B. (2014). Supply Chain Risk Management. DNVGL Business Assurance. Linkoping University Electronic Press.

[5] Best Practice Network. (2006). E-Sourcing: A Buy IT EProcurement Best Practice Guideline. Special Issue 2006, 123.

[6] Best Practice Network. (2004). E-Sourcing: A BuyIT eProcurement Best Practice Guideline. Bristol: Best Practice Network.

[7] Bosman, R. (2006). The New Supply Chain Challenge: Risk Management in a Global Economy. USA: FM Global.

[8] Braunscheidela, M. J. (2009). The organizational antecedents of a firm's supply chain agility for risk mitigation and response. Journal of Operations Management, 27 (2), 119-140.

[9] Chopra, S. A., Sodhi, M. S. (2014). Managing the Cost of Risk Reduction in the Supply Chain. The European Financial review. Procurement \& Supply Chain, Risk Intelligence, UK.vol 12(2), 68-70.

[10] Department of Transport UK. (2003). Creating Resilient Supply Chains: Practical Guide. Centre for Logistics and Supply Chain Management, Cranfield, Bedford. United Kingdom Mk43 0AL.

[11] Dittmann, P. (2014). Managing Risk in the Global Supply Chain. Corporate Partnerships, Knoxville, University of Tennessee, United Kingdom.

[12] DNVGL. (2015, January 2). Supply Chain Risk Management Sustainable performance is not only about what you do. You are also judged on the actions of your suppliers. . Retrieved October 6th, 2015, from DNVGL: https://www.dnvgl.com/services/supply-chain-riskmanagement--5108.

[13] Giunipero, L. (2000). World-class Purchasing Skills: An Empirical An Investigation. Journal of Supply Chain Management, 36 (4) 4-13.

[14] Larson, P. a. (1998). Single Sourcing and Supplier Certification: Performance and Relationship Implications. Industrial Marketing Management, 27 (1), 73-81. New Delhi, Wiley Eastern Limited.

[15] Lee, H. P. (1997). Information Distortion in a Supply Chain: The Bullwhip Effect. Management Science, 43 (4), 546-580.

[16] MacKinnon, M. (2002). The Security Team: These Online Services Back Up B2B Security, International Journal of Physical Distribution \& Logistics Management, 34 (9), 608714.

[17] Manuj, I. (2008). Global supply chain risk management strategies. International Journal of Physical Distribution \& Logistics Management, 38 (3), 192223.

[18] Norrman, A. (2004). Ericsson's proactive supply chain risk management approach after a serious sub-supplier accident. International Journal of Physical. Distribution \& Logistics Management, 34 (5), 434-456.
[19] Nurmaya, S. (2012). Supply Chain Risk Management: Identification, Evaluation and Mitigation Techniques. Linköping Studies in Science and Technology, Dissertations, No. 1459 .

[20] Okonjo, E. (2014). Procurement Risk Management Practices and Supply Chain Performance of Mobile Phone Service Providers in Kenya. Nairobi, University of Nairobi Press.

[21] Simon, K. M. (2011). Correlational Research: Dissertation and Scholarly Research: Recipes for Success. Seattle, WA: Dissertation Success LLC, 40 (1), 69-72.

[22] Singh, K. (1998). The Impact of Technological Complexity and Inter Firm Cooperation on Business Surviva. Academy of Management Journal, 40, (2), 339-69.

[23] Smeltzer, L. (1998). Proactive Supply Management: The Management of Risk. International Journal of Purchasing and Materials Management, 34 (1), 38-45.

[24] Snow, J. (2013). Procurement Performance Indicators Guide Using Procurement Performance Indicators to Strengthen the Procurement Process for Public Health ommodities. U.S., Agency for International Development, 34(3), 156-168.

[25] Spiers, D. (2010). Effective Operations Performance Management: Strategic Framework for Success.United States of America, Westin Press.

[26] Stading, G. A. (2000). University of Houston-Downtown 92nd Annual International Supply Management Conference, May 2007.

[27] The Vehicle Builders \& Repairers Association. (2015, August 5). Support services to the Motor Industry. Nairobi, centre graphic services.

[28] Thun J. and Hoenig, D. (2011). An Empirical Analysis of Supply Chain Risk Management in the German Automotive Industry. International Journal of Production Economics, 131 (1), 242-249.

[29] Tomas, R. N. (2013). Linking External Integration to Supply Chain Risk Reduction and Performance Outcomes: An Empirical Study 22, (2), 223-234.

[30] Tsikriktsis, N. (2007). The Effect of Operational Performance and Focus on Profitability: A Longitudinal Study of the U.S. Airline Industry. Manufacturing \& Service Operations Management, 9 (4), 506-517.

[31] Truck World. (2015). Truck World. Retrieved October 11, 2015, from About Us: http://www.truckworld.co.za/

[32] USAID. (2013). Procurement Performance Indicators Guide: Using Procurement Performance Indicators to Strengthen the Procurement Process for Public Health Commodities. Kansas city, USAID.

[33] Zsidisin, G. (2013). Managerial Perceptions of Supply Risk. Journal of Supply Chain Management, 39 (1), 14-25.

[34] Zsidisin, G. P. (2001). Purchasing Organization Involvement in Risk Assessments, Contingency Plans, and Risk Management: An Exploratory Study. Supply Chain Management, 5 (4) 187 - 202. 